\title{
Effects of salt stress and nitrogen application on growth and ion accumulation of Suaeda salsa plants
}

\author{
Bo Guan ${ }^{1,2}$, Junbao Yu ${ }^{1, *}$, Xiaobing Chen ${ }^{1}$ \\ 1 Laboratory of Coastal Wetland Ecology, Key Laboratory \\ of Coastal Zone Environmental Processes, Yantai Institute \\ of Coastal Zone Research, Chinese Academy of Sciences. \\ Yantai, 264003, P. R. China \\ 2 Graduate University of Chinese Academy of Sciences, \\ Beijing, 100049, China \\ *Email: junbao.yu@gmail.com and jbyu@yic.ac.cn
}

\begin{abstract}
Suaeda salsa is a typical pioneer species which can grow well in high salt environmental conditions. The objective of this study is to evaluate the effect of different levels of salinity $(5.25,10.5$ and $21 \mathrm{~g} \mathrm{NaCl}$ per kg soil) and nutrient supply $(0,0.3,0.6$ and $1.2 \mathrm{~g}$ urea per kg soil) on plant morphology, biomass, accumulation of ions and $\mathrm{C} / \mathrm{N}$ ratio in leaves of $S$. salsa. The results showed that the plant height, number of branches, length of branches and diameter of shoot were significantly affected by salt stress, and the nitrogen released the negative effects of salt. The nitrogen treatment increased the biomass of leaf, shoot and root. Leaf water content was significantly affected by the interaction of salt stress and nitrogen treatment. The content of $\mathrm{Na}^{+}$and $\mathrm{Cl}^{-}$increased significantly as increasing of salt, the content of $\mathrm{K}^{+}, \mathrm{Ca}^{2+}$, $\mathrm{Mg}^{2+}$ and $\mathrm{SO}_{4}{ }^{2-}$ decreased simultaneously to keep ion balance. The $\mathrm{C} / \mathrm{N}$ ratio decreased significantly as increasing of nitrogen treatment. The content of proline increased significantly with the increasing of salt and nitrogen treatments. The results together indicated that at different salt environment, different amount of nitrogen supply can be used to improve the population growth of $S$. salsa plants, and the restoration of degraded wetland could be accelerated by nutrient supply reasonably.
\end{abstract}

Keywords-nitrogen; potassium; salt stress; seedlings; sodium; Suaeda salsa

\section{INTRODUCTION}

The Yellow River Delta is one of the most active regions of land-ocean interaction among large river deltas in the world. Wetlands in the Yellow River Delta support a wide variety of flora and fauna, in which there are two hundred and twenty different kinds of plant species and more than 800 animal species, including 199 kinds of bird. The Yellow River Delta has become an important over-wintering and breeding site for migrating birds in Northeast Asian Inland and Western Pacific Rim $^{[1]}$. But in recent years, low flows of the Yellow River

\author{
Wenjun Xie, Zhaohua Lu* \\ Research Center for Eco-Environmental Sciences Yellow \\ River Delta, \\ Binzhou University, \\ Binzhou, 256603, China \\ *Email: 1u-zhh@,263.net
}

have led to a decrease in fresh water supply to the wetlands, and soluble salts in groundwater are carried to the surface in the form of capillary water, then water evaporates and salt is left in the top soil, resulting in a substantial rise in soil salinity ${ }^{[1]}$, which bring out an urgent need to develop salttolerant plant species to overcome the soil salinity problem.

Suaeda salsa (L.), a succulent halophytic herb, widely distributed in northeast China, naturally grows on inland saline soils and coastal saline wetland ${ }^{[2]}$. Leaves of $S$. salsa can absorb many salt ions, which made them sustain high salt environment during germination and seedling stage. Fresh shoots of $S$. salsa are very valuable as a vegetable, and its seeds can produce edible oil ${ }^{[3]}$. S. salsa salt marsh, covering most forelands in the Yellow River Delta, is important to keep the natural succession of the wetland eco-system. The optimum soil salinity for $S$. salsa was about $12.71 \mathrm{~g} / \mathrm{kg}^{[4]}$. In recent decades, with the exploitation of wetland resources and the rush of environmental problems, this habitat suitable to $S$. salsa is degrading.

Salt resistance in plants is usually quantified in terms of survival rates ${ }^{[5]}$ and/or growing abilities under stress conditions, involving biochemical and physiological processes as well as morphological and developmental changes ${ }^{[6]}$, and previous studies ${ }^{[7,8]}$ have indicated that the maintenance of an adequate supply of nutrients to the growth zone should be a key component of the growth response to salinity. Nitrogen fertilization could increase crop yield ${ }^{[9]}$, and the application of nitrogen fertilizer has also been reported to mitigate significantly the adverse effects caused by high salt stress on a number of plants ${ }^{[10,11]}$.

Therefore, information on the biological and ecophysiological characteristics of $S$. salsa is needed to aid use in protecting the environment and developing saline agriculture. In the present study, the morphological changes and physiological processes under different $\mathrm{NaCl}$ and nitrogen levels were determined to investigate the adaptation mechanisms of $S$. salsa to different salt levels and how nitrogen supply can alleviate the harm effects of salt environment. 


\section{MATERIALS AND METHODS}

\section{A. Plant materials}

Seeds of Suaeda salsa (L.) were collected from Yellow River Delta in autumn 2008 before using in April 2009. Seeds were surface-sterilized with $3 \%$ sodium hypochlorite for $5 \mathrm{~min}$, followed by a thorough rinsing with deionized water. Seeds were sown in $25 \mathrm{~cm}$ diameter plastic pots that contained $4 \mathrm{~kg}$ of native loamy soils in a partially shaded greenhouse under maximum photosynthetically active radiation of $1000 \mu \mathrm{mol} \mathrm{m} \mathrm{m}^{-2} \mathrm{~s}^{-1}$, day/night temperature of $30 / 24 \pm 3^{\circ} \mathrm{C}$. The native loamy soils were totally mixed before used. The total nitrogen, available phosphorus, and potassium of the soil were, respectively, $1.12 \mathrm{~g} \mathrm{~kg}^{-1}, 12.9 \mathrm{mg} \mathrm{kg}^{-1}$, and $203.6 \mathrm{mg} \mathrm{kg}^{-1}$, and the total salt content were $2.22 \mathrm{~g} \mathrm{~kg}^{-1}$.

\section{B. Greenhouse experiments}

1) The treatments combined four levels of nutrient supply with three salt levels in a factorial (nutrient $\times$ salt) design, with four replicates. The four levels of nutrient supply were $0,1.2$, 2.4 and $4.8 \mathrm{~g}$ slow-release urea per container (signed as $\mathrm{NN}$, $\mathrm{LN}, \mathrm{MN}$ and $\mathrm{HN}$ ), and the three salt levels were 21, 42 and 84 g NaCl per container (signed as LS, MS and HS), and no salt no nitrogen treatment was used as control (C). A total of 52 pots were randomly placed in the same greenhouse as seedling culture. Slow-release urea and $\mathrm{NaCl}$ were thoroughly mixed into the soil. During the early growth stages (plants did not show much difference in response to salt), equal amounts of water were applied and the salt solution was maintained at 1 $\mathrm{cm}$ deep in the saucers. When plants started to show differences in their salt tolerance, a different amount of water was applied to each pot to make sure that the salinity level in different pots was maintained as uniformly as possible ${ }^{[12]}$.

2) Seedlings were thinned to $13-15$ per pot after 7 days of sowing. The treatment normally lasted for 2 months. At the end of the experiments, the plant height, total branch number, the length of each branch and diameter of shoot of 7 plants in each pot were measured. Then plants were harvested, they were first washed with tap water, then distilled water. Roots, shoots and leaves were separated and the FW was determined for each plant, and the samples were oven-dried at $105^{\circ} \mathrm{C}$ for $15 \mathrm{~min}$, then vacuum-dried at $60^{\circ} \mathrm{C}$ to constant weight and the DW was recorded.

3) Dry samples of plant leaf (100 mg) were treated with 20 $\mathrm{ml}$ deionized water at $100^{\circ} \mathrm{C}$ for $20 \mathrm{~min}$ and the extract was taken to determine free anion contents. The contents of $\mathrm{NO}_{3}{ }^{-}$, $\mathrm{Cl}^{-}$, and $\mathrm{SO}_{4}{ }^{2-}$ in leaves were determined by ion chromatography (ICS-2000, Dionex, USA). A $400 \mathrm{mg}$ dry sample of plant leaf was wet ashed with $\mathrm{H}_{2} \mathrm{SO}_{4}$ : $\mathrm{HClO}_{4}(10: 1$, $\mathrm{v} / \mathrm{v}$ ) digestion, and then brought to a volume of $100 \mathrm{ml}$ with deionized water. Atomic emission spectrometry (AA-6800, Shimadzu, Japan) were used for the determination of sodium $(\mathrm{Na})$, potassium $(\mathrm{K})$, calcium $(\mathrm{Ca})$ and magnesium $(\mathrm{Mg})$ concentrations. Total $\mathrm{N}$ and $\mathrm{C}$ in leaves were analyzed by elemental analyzer (Elementar Vario Macro, Germany). Leaf
$\mathrm{C} / \mathrm{N}$ ratio was then calculated. The contents of proline were measured in dry samples. Proline was measured using ninhydrin $^{[13]}$.

4) Statistical analysis of the data, which involved data processing and variance analysis (ANOVA), was conducted using SPSS 11.5 (SPSS Inc., Chicago, IL, USA). Experimental data were subjected to two way analysis of variance (salt level and nitrogen supply as main factors) and the means were separated by the least significant difference (LSD). All acquired data were represented by an average of 3-4 replicate (one replicate per pot) measurements and standard deviation (S.D.). Significance was tested at the 5\% level.

\section{RESULTS}

\section{1) Responses of plant morphology to $\mathrm{NaCl}$ and Nitrogen}

Plant height decreased with the increasing of salt stress, but it was not affected significantly by LS stress (Table 1). At LSMN treatment, S. salsa plants have more branches and longer shoot diameter than any other treatments. At LS treatment, the mean length of branches was significantly longer than control and all other treatments except in MSHN treatment. At MS and HS treatments, $\mathrm{LN}$ and MN increased the plant height, number of branches and branch length significantly compared with control (Table 1).

2) Leaf water content and plant biomass

The leaf water content (LWC) was significantly affected by the interaction of $\mathrm{NaCl}$ and nitrogen (Table 3). Compared with control, the leaf water content of $S$. salsa increased significantly, except at LSHN and MSLN treatment (Fig. 1, Table 3$)(P<0.05)$. The LWC increased significantly with the increasing of salt stress at $\mathrm{HN}$ treatment (Fig. 1) $(P<0.05)$. The total and leaf biomass were significantly affected by salt stress (Table 3 ). Compared with control, Biomass of S. salsa was significantly affected by MS and HS (Table 2). The biomass of leaf, shoot and root of $S$. salsa plants treated by LSMN were two-fold higher than those of LSNN treatment (Table 2), and at MS and HS treatments, LN and MN increased the biomass of leaf, shoot and root of $S$. salsa seedlings except the root biomass at HNHM treatment.

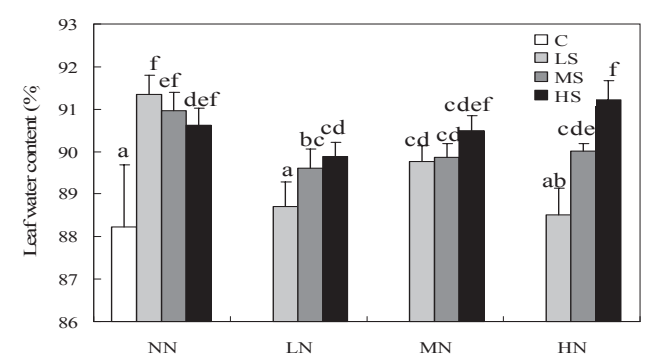

Figure 1. The effect of salt stress and nitrogen treatment on leaf water content (LWC) of $S$. salsa seedlings. The values are means $( \pm$ S.D.) of three replicates. Different letters indicate significant differences from each other 
TABLE1. Plant height, number of branches, length of branches and diameter of shoot of $S$. salsa seedlings under different salt and nitrogen treatments. The values are means $( \pm$ S.D.) of three replicates. Different capital letters indicate significant differences from different salt levels, and different lowercase letters indicate significant differences from different nitrogen levels $(P<0.05)$.

\begin{tabular}{cccccc}
\hline \multirow{2}{*}{ Index } & Nitrogen & \multicolumn{4}{c}{ Salt treatments } \\
\cline { 3 - 6 } & treatments & $\mathrm{C}$ & $\mathrm{LS}$ & $\mathrm{MS}$ & $\mathrm{HS}$ \\
\hline & $\mathrm{C}$ & $27.0 \pm 0.22 \mathrm{~A}$ & $26.0 \pm 1.68 \mathrm{Aa}$ & $14.5 \pm 0.84 \mathrm{Bb}$ & $10.3 \pm 0.33 \mathrm{Ca}$ \\
Plant height & $\mathrm{LN}$ & - & $24.1 \pm 1.19 \mathrm{Aa}$ & $16.7 \pm 0.31 \mathrm{Ba}$ & $12.9 \pm 0.40 \mathrm{Ca}$ \\
$(\mathrm{cm})$ & $\mathrm{MN}$ & - & $24.3 \pm 2.03 \mathrm{Aa}$ & $15.6 \pm 0.24 \mathrm{Bab}$ & $12.4 \pm 1.33 \mathrm{Ba}$ \\
& $\mathrm{HN}$ & - & $24.6 \pm 1.54 \mathrm{Aa}$ & $14.7 \pm 0.75 \mathrm{Bb}$ & $10.7 \pm 0.93 \mathrm{Ba}$ \\
\hline & $\mathrm{C}$ & $7.4 \pm 0.49 \mathrm{~A}$ & $8.6 \pm 0.84 \mathrm{Ab}$ & $3.8 \pm 0.62 \mathrm{Bb}$ & $3.8 \pm 0.33 \mathrm{Ba}$ \\
Number of & $\mathrm{LN}$ & - & $8.6 \pm 0.87 \mathrm{Ab}$ & $5.9 \pm 0.22 \mathrm{Ba}$ & $4.9 \pm 0.36 \mathrm{Ba}$ \\
branches & $\mathrm{MN}$ & - & $12.6 \pm 0.61 \mathrm{Aa}$ & $6.0 \pm 0.58 \mathrm{Ba}$ & $4.9 \pm 0.83 \mathrm{Ba}$ \\
& $\mathrm{HN}$ & - & $10.1 \pm 1.12 \mathrm{Ab}$ & $5.1 \pm 0.05 \mathrm{Bab}$ & $3.6 \pm 0.52 \mathrm{Ba}$ \\
\hline & $\mathrm{C}$ & $-0.12 \mathrm{~B}$ & $7.7 \pm 0.68 \mathrm{Aa}$ & $3.8 \pm 0.66 \mathrm{Cb}$ & $3.0 \pm 0.07 \mathrm{Cb}$ \\
Length of & $\mathrm{LN}$ & - & $7.7 \pm 0.13 \mathrm{Aa}$ & $5.8 \pm 0.18 \mathrm{Ba}$ & $4.8 \pm 0.20 \mathrm{Ca}$ \\
branches & $\mathrm{MN}$ & - & $8.7 \pm 0.33 \mathrm{Aa}$ & $5.5 \pm 0.39 \mathrm{Ba}$ & $4.1 \pm 0.20 \mathrm{Cb}$ \\
$(\mathrm{cm})$ & $\mathrm{HN}$ & $-7.6 \pm 0.65 \mathrm{Aa}$ & $6.1 \pm 0.34 \mathrm{Aa}$ & $3.3 \pm 0.73 \mathrm{Bb}$ \\
\hline & $\mathrm{C}$ & - & $1.73 \pm 0.08 \mathrm{Ab}$ & $1.11 \pm 0.01 \mathrm{Bc}$ & $1.02 \pm 0.03 \mathrm{Bb}$ \\
Diameter of & $\mathrm{LN}$ & $1.82 \pm 0.02 \mathrm{~A}$ & $1.84 \pm 0.06 \mathrm{Ab}$ & $1.30 \pm 0.04 \mathrm{Ba}$ & $1.18 \pm 0.02 \mathrm{Ba}$ \\
shoot & $\mathrm{MN}$ & - & $2.08 \pm 0.06 \mathrm{Aa}$ & $1.23 \pm 0.00 \mathrm{Bb}$ & $1.13 \pm 0.07 \mathrm{Bab}$ \\
$($ mm) & $\mathrm{HN}$ & $1.69 \pm 0.16 \mathrm{Ab}$ & $1.21 \pm 0.01 \mathrm{Bb}$ & $1.02 \pm 0.03 \mathrm{Bb}$ \\
\hline
\end{tabular}
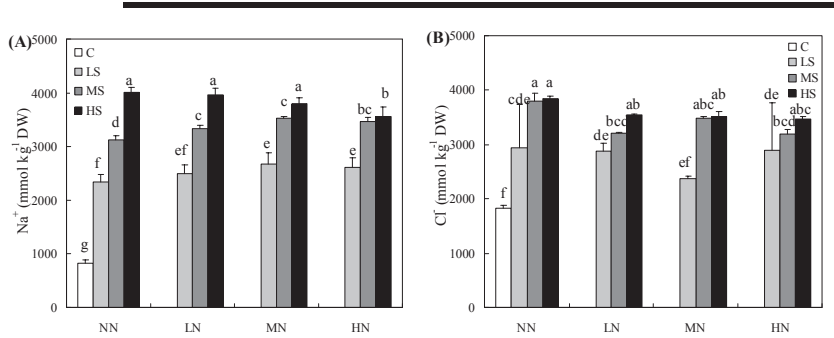

decreased significantly compared with control, and the $\mathrm{K}^{+}$ content was higher in LS stress than in MS and HS stress except HSMN treatment (Fig. 2C). The changes of $\mathrm{Ca}^{2+}$ and $\mathrm{Mg}^{2+}$ are similar with $\mathrm{K}^{+}$, which decreased with the increase of salt. $\mathrm{Ca}^{2+}, \mathrm{Mg}^{2+}$ and $\mathrm{K}^{+}$all decreased significantly compared with control resulted from the interaction effect of nitrogen and salt treatment (Fig. 2E, G).

Under salt stress, the $\mathrm{Cl}^{-}$content in leaves increased with
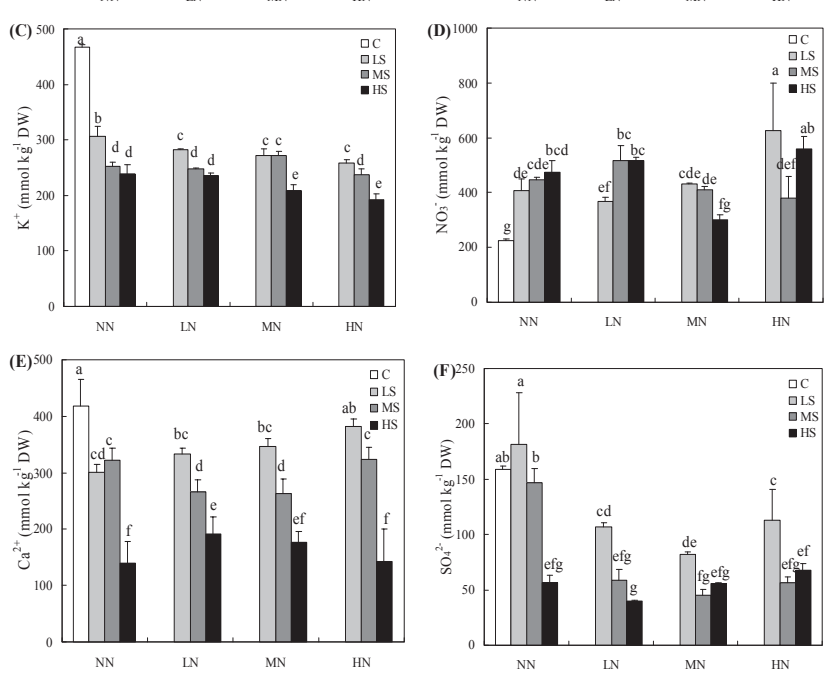

increasing salinity (Fig. 2B). The content of $\mathrm{NO}_{3}{ }^{-}$increased clearly as the interaction effect of nitrogen and salt treatment compared with control, except for HSMN treatment.But as the increase of nitrogen treatment, the content of $\mathrm{Cl}^{-}$and $\mathrm{NO}_{3}{ }^{-}$ remained relatively unchanged (Fig. 2B, D). The nitrogen treatment affected the content of $\mathrm{SO}_{4}{ }^{2-}$ significantly, which were much lower in all nitrogen treatment than in $\mathrm{NN}$ treatment. Compared with salt stresses, the MS and HS decreased the $\mathrm{SO}_{4}{ }^{2-}$ content more significantly than LS (Fig. 2F).

The $\mathrm{C} / \mathrm{N}$ ratio in leaves was shown in Fig. 3. The control group had the highest $\mathrm{C} / \mathrm{N}$ ratio. As the nitrogen content in the soils increase, the $\mathrm{C} / \mathrm{N}$ ratio decreased significantly (Table 3 ) $(P<0.001)$. The salt stress did not affect the $\mathrm{C} / \mathrm{N}$ ratio, but the interactions of nitrogen and salt stress significantly affected the $\mathrm{C} / \mathrm{N}$ ratio (Table 3) $(P<0.001)$.

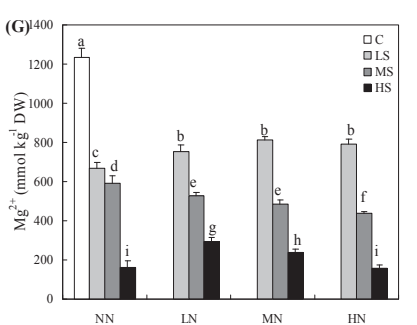

Figure 2. The effect of salt stress and nitrogen treatment on $\mathrm{Na}^{+}, \mathrm{K}^{+}$, $\mathrm{Ca}^{2+}, \mathrm{Mg}^{2+}$ and $\mathrm{Cl}^{-}, \mathrm{NO}_{3}{ }^{-}$and $\mathrm{SO}_{4}{ }^{2-}$ in leaves of $\mathrm{S}$. salsa seedlings. The values are means $( \pm$ S.D. $)$ of three replicates Different letters indicate significant differences from each other $(P<0.05)$

\section{3) Responses of plant Physiology to $\mathrm{NaCl}$ and Nitrogen}

With increasing of salt stress, $\mathrm{Na}^{+}$content of leaves increased significantly (Fig. 2A). In contrast, the $\mathrm{K}^{+}$content

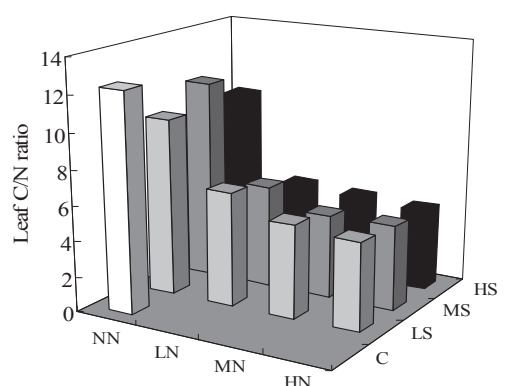

Figure 3. The effect of salt stress and nitrogen treatment on $\mathrm{C} / \mathrm{N}$ ratio in leaves of $S$. salsa seedlings. Each value is means ( \pm S.D.) of three replicates. 
TABLE 2. The biomass of leaf, shoot and root of $S$. salsa seedlings under different salt and nitrogen treatments. The values are means $( \pm$ S.D.) of three replicates. Different capital letters indicate significant differences from different salt levels, and different lowercase letters indicate significant differences from different nitrogen levels $(P<0.05)$.

\begin{tabular}{cccccc}
\hline \multirow{2}{*}{ Biomass } & Nitrogen & \multicolumn{4}{c}{ Salt treatments } \\
\cline { 3 - 6 } & treatments & $\mathrm{C}$ & $\mathrm{LS}$ & $\mathrm{MS}$ & $\mathrm{HS}$ \\
\hline Leaf & $\mathrm{C}$ & $0.311 \pm 0.024 \mathrm{~A}$ & $0.287 \pm 0.028 \mathrm{Ab}$ & $0.093 \pm 0.017 \mathrm{Bb}$ & $0.066 \pm 0.009 \mathrm{Bb}$ \\
(g/plant) & $\mathrm{LN}$ & - & $0.449 \pm 0.049 \mathrm{Ab}$ & $0.198 \pm 0.006 \mathrm{Ba}$ & $0.125 \pm 0.011 \mathrm{Ba}$ \\
& $\mathrm{MN}$ & - & $0.678 \pm 0.038 \mathrm{Aa}$ & $0.176 \pm 0.005 \mathrm{Ba}$ & $0.108 \pm 0.024 \mathrm{Bab}$ \\
& $\mathrm{HN}$ & - & $0.466 \pm 0.103 \mathrm{Ab}$ & $0.167 \pm 0.006 \mathrm{Ba}$ & $0.069 \pm 0.017 \mathrm{Bb}$ \\
\hline & $\mathrm{C}$ & $0.191 \pm 0.012 \mathrm{~A}$ & $0.151 \pm 0.018 \mathrm{Bc}$ & $0.039 \pm 0.009 \mathrm{Cc}$ & $0.021 \pm 0.003 \mathrm{Cb}$ \\
Shoot & $\mathrm{LN}$ & - & $0.203 \pm 0.019 \mathrm{Abc}$ & $0.081 \pm 0.003 \mathrm{Ba}$ & $0.043 \pm 0.004 \mathrm{Ba}$ \\
(g/plant) & $\mathrm{MN}$ & - & $0.311 \pm 0.020 \mathrm{Aa}$ & $0.067 \pm 0.001 \mathrm{Bab}$ & $0.039 \pm 0.010 \mathrm{Bab}$ \\
& $\mathrm{HN}$ & - & $0.265 \pm 0.069 \mathrm{Aab}$ & $0.059 \pm 0.001 \mathrm{Bbc}$ & $0.022 \pm 0.007 \mathrm{Bb}$ \\
\hline & $\mathrm{C}$ & $0.083 \pm 0.006 \mathrm{~A}$ & $0.047 \pm 0.005 \mathrm{Bb}$ & $0.010 \pm 0.001 \mathrm{Cb}$ & $0.005 \pm 0.000 \mathrm{Ca}$ \\
Root & $\mathrm{LN}$ & - & $0.087 \pm 0.010 \mathrm{Aa}$ & $0.014 \pm 0.001 \mathrm{Ba}$ & $0.008 \pm 0.000 \mathrm{Ba}$ \\
(g/plant) & $\mathrm{MN}$ & - & $0.092 \pm 0.004 \mathrm{Aa}$ & $0.012 \pm 0.000 \mathrm{Bab}$ & $0.008 \pm 0.002 \mathrm{Ba}$ \\
& $\mathrm{HN}$ & - & $0.053 \pm 0.013 \mathrm{Ab}$ & $0.011 \pm 0.000 \mathrm{Bb}$ & $0.006 \pm 0.001 \mathrm{Ba}$ \\
\hline
\end{tabular}

TABLE 3. Two-way ANOVAs on total biomass, leaf biomass, leaf water content $(\%)$ and leaf $\mathrm{C} / \mathrm{N}$ ratio of $\mathrm{S}$. Salsa for $\mathrm{NaCl}$ and Nitrogen treatment and their interactions.

\begin{tabular}{ccccc}
\hline \multicolumn{2}{c}{ Independent variable } & $\mathrm{NaCl}$ & Nitrogen & $\mathrm{NaCl} \times$ Nitrogen \\
\hline Total biomass & $\mathrm{F}$ & 55.817 & 5.314 & 2.652 \\
& $p$ - values & 0.000 & 0.005 & 0.035 \\
Leaf biomass & $\mathrm{F}$ & 61.718 & 7.414 & 3.577 \\
& $p$ - values & 0.000 & 0.001 & 0.009 \\
Leaf water content & $\mathrm{F}$ & 22.060 & 10.587 & 5.392 \\
& $p$ - values & 0.000 & 0.000 & 0.001 \\
Leaf C/N ratio & $\mathrm{F}$ & 925.441 & 15843.24 & 207.884 \\
& $p$ - values & 0.000 & 0.000 & 0.000 \\
\hline
\end{tabular}

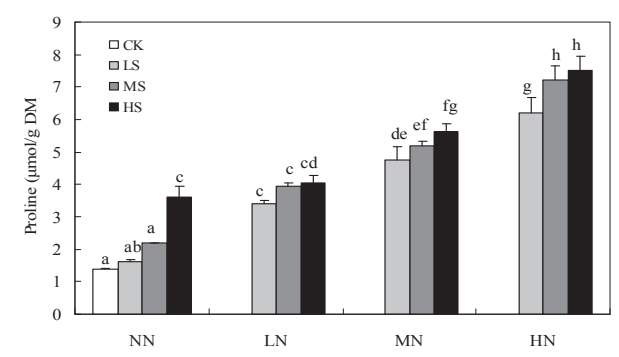

Figure 4. The effect of salt stress and nitrogen treatment on proline contents of $S$. salsa seedlings.

The responses of proline content to salt were similar to that of $\mathrm{Na}^{+}$, which increased significantly with the increasing of salt stress, but also increased significantly with the increasing of nitrogen treatment.

\section{DISCUSSION}

Water deficit and salt-specific or ion-excess affected by salinity are the main reasons which inhibit plant growth ${ }^{[14]}$, but different plant species have developed different mechanisms to cope with these effects ${ }^{[15]}$. In this work, higher salt treatment significantly affected the plant height, number of branches, mean length of branches and diameter of shoot (Table 1), which were consistent with the results reported by Liu et al. ${ }^{[16]}$. S. salsa is a typical halophyte which can grow better in salt environment ${ }^{[4]}$, and it needs more inorganic ions to adjust the osmotic potential and physiological needs. This is demonstrated in Table 1: there were no significant affects for plant height, number of branches and shoot diameter between
LS and control treatments, however, the mean length of branches was longer in LS treatment than that of control group. The results indicated that the $S$. salsa plants needed more inorganic ions for better growth, and LS was the best level that contained suitable ions to $S$. salsa plants in this study. Such characteristics are favorable for $S$. salsa plants to grow well in coastal wetlands in Yellow River Delta and decrease the evaporation through accumulating high above-ground biomass in saline areas. Previous studies have shown that higher nutrient supply may provide more nutrient for plant growth and counteract the negative effects caused by the surrounding conditions, such as salts ${ }^{[16,17]}$, and flood $^{[18,19]}$. In this study, it showed that $S$. salsa plants accumulated more biomass over the same growth period in the presence of different levels of nitrogen and LS treatment (Table 2, 3). However, in MS and HS treatments, although nitrogen treatment increased the biomass of leaf, shoot and root, there were no significant differences between $\mathrm{LN}$ and $\mathrm{MN}$ treatments. Generally, plants can reduce water content as a quick and economical approach to osmotic adjustment in response to osmotic stress ${ }^{[20,21]}$. Unexpectedly, the LWC in all salt treatments were higher than control (Fig. 1, Table 3). Being a succulent plant, maintaining high LWC can make vacuoles enlarging, which cause the cell surface to increase and make the layer of protoplasm thinner. Cell surface area and the distance between plasmalemma and vacuole membranes are key factors in deciding the speed and power of consumption of inorganic ions and organic small molecules going in and out of each cell ${ }^{[21]}$. So this might be one of the main physiological characteristics of $S$. salsa that allow it to have strong resistance to salt stress.

It has been generally observed that plants exposed to saline environment $(\mathrm{NaCl})$, take up high amounts of $\mathrm{Na}^{+}$, whereas the uptake of $\mathrm{K}^{+}$and $\mathrm{Ca}^{2+}$ is significantly reduced ${ }^{[15,22,23]}$. Plants generally compartmentalize $\mathrm{Na}^{+}$into vacuoles to avoid $\mathrm{Na}^{+}$toxicity in the cytosol ${ }^{[24]}$. Thus, $\mathrm{Na}^{+}$is the main inorganic osmolyte under salt stress. $\mathrm{Ca}^{2+}$ can maintain membrane stability, help to form cell walls and take part in signal transduction. $\mathrm{Mg}^{2+}$ is the key component of chlorophyll. But the $\mathrm{Ca}^{2+}$ and $\mathrm{Mg}^{2+}$ accumulation in many plants (include halophytes) are inhibited by salt stress ${ }^{[25,26]}$. In the present 
study, the amount of $\mathrm{Na}^{+}$increased significantly as the increased of salt stress, and for maintain cations balance in plant cells, the content of $\mathrm{K}^{+}, \mathrm{Ca}^{2+}$ and $\mathrm{Mg}^{2+}$ decreased simultaneously (Fig. 2). The amount of cations was not affected significantly by nitrogen. This phenomenon could be explained that cations were more sensitive to high salt stress than nitrogen treatments. Under salt stress, plants accumulate cations such as $\mathrm{Na}^{+}$and $\mathrm{K}^{+[22]}$, and simultaneously accumulate inorganic anions such as $\mathrm{Cl}^{-[21]}, \mathrm{NO}_{3}^{-}$and $\mathrm{SO}_{4}{ }^{2-[27]}$ to keep ion balance. In this study, the content of $\mathrm{Cl}^{-}$and $\mathrm{NO}_{3}{ }^{-}$increased in salt treatments compared with control, and for the anions balance, $\mathrm{SO}_{4}{ }^{2-}$ decreased as the increasing of salt stress.

Proline is organic osmolyte distributed principally in protoplasm. The accumulation of proline is clearly the response to osmotic stress to salt and nitrogen addition. It is possibly related to their strong resistance to salt tress.

Carbon metabolism and nitrogen metabolism are the two basic metabolism processes in plant development. They directly affect the formation and transformation of the photosynthetic product, mineral nutrition absorption, and protein synthesis. Their ratio $(\mathrm{C} / \mathrm{N}$ ratio) reflects the accordant status of carbon and nitrogen metabolism ${ }^{[28]}$. In this study, with the increasing of nitrogen treatments, the nitrogen uptake increased, and the $\mathrm{C} / \mathrm{N}$ ratio in leaves decreased significantly (Fig. 3, Table 3). This indicated that nitrogen supply could increase metabolic activity of nitrogen and then increase the biomass of plant ${ }^{[28]}$. This could be another important physiological characteristic for $S$. salsa to maintain normal carbon and nitrogen metabolism under high salt stress.

\section{REFERENCES}

[1] B. S. Cui, Q. C. Yang, Z. F. Yang, K. J. Zhang, "Evaluating the ecological performance of wetland restoration in the Yellow River Delta, China". Ecological Engineering, 2009, 35: 1090-1103.

[2] B. S. Wang, U. Luttge, R. Ratajczak, "Specific regulation of SOD isoforms by $\mathrm{NaCl}$ and osmotic stress in leavrs of the $\mathrm{C} 3$ halophyte Suaeda salsa L.” Journal of Plant Physiology, 2004, 161: 285-293

[3] K. F. Zhao, H. Fan, X. Y. Jiang, S. Zhou, "Critical day-length and photoinductive cycles for the induction of flowering in halophyte Suaeda salsa", Plant Science, 2002, 162: 27-31

[4] B. S. Cui, Q. He, X. S. Zhao, "Ecological thresholds of Suaeda salsa to the environmental gradients of water table depth and soil salinity". Acta Ecologica Sinica, 2008, 28(4): 1408-1418

[5] B. Guan, D. Zhou, H. Zhang, Y. Tian, W. Japhet, P. Wang, "Germination responses of Medicago ruthenica seeds to salinity, alkalinity, and temperature". Journal of Arid Environments, 2009, 73: 135-138

[6] M. Yildiz, and E. Kasap, "Comparison of germination responses of cultivated wheat (Triticum) and its wild relative (Aegilops) species under salinity, temperature and light". Acta Agronomy Hungarica, 2007, 55, 407-415

[7] Y. C. Hu, Fricke Wieland, Schmidhalter Urs. "Salinity and the growth of non-halophytic grass leaves: the role of mineral nutrient distribution." Functional Plant Biology, 2005, 32: 973-985

[8] V. Gimeno, J.P. Syvertsen, M. Nieves, I. Simón, V. Martínez, F. GarcíaSa'nchez, "Additional nitrogen fertilization affects salt tolerance of lemon trees on different rootstocks". Scientia Horticulturae, 2009, 121: 298-305"

[9] Ch. Noulas, P. Stamp, A. Soldati, and M. Liedgens, "Nitrogen use efficiency of spring wheat genotypes under field and lysimeter conditions". Journal of Agronomy and Crop Science, 2004, 190: 111118

[10] E. O. Leidi, M. Silberbush, S. H. Lips. "Wheat growth as affected by nitrogen type, $\mathrm{pH}$ and salinity. I. Biomass production and mineral composition". Journal of Plant Nutrition, 1991, 14: 235-243

[11] J. Song, X. D. Ding, G. Feng, F. S. Zhang, "Nutritional and osmotic roles of nitrate in a euhalophyte and a xerophyte in saline conditions". New Phytologist, 2006, 171: 357-366

[12] Z. H. Chen, S. Shabala, Neville Mendham, Ian Newman, G. P. Zhang, and M. X. Zhou, "Combining Ability of Salinity Tolerance on the Basis of NaCl-Induced $\mathrm{K}^{+}$Flux from Roots of Barley". Crop Science, 2008, 48: $1382-1388$

[13] G. L. Zhu, X. W. Deng, W. N. Zuo, "Determination of free proline in plants". Plant Physiology Communnications, 1983, 1:35-37

[14] R. Munns, R. A. James, A. L"auchli, "Approaches to increasing the salt tolerance of wheat and other cereals". Journal of Experimental Botany, 2006, 57: 1025-1043

[15] R. Munns, "Comparative physiology of salt and water stress". Plant Cell and Environment, 2002, 25, 239-250

[16] X. J. Liu, Y. M. Yang, W. Q. Li, C. Z. Li, D. Y. Duan, Tadano Toshiaki. "Interactive Effects of Sodium Chloride and Nitrogen on Growth and Ion Accumulation of a Halophyte". Communications in Soil Science and Plant Analysis, 2004, 35: 2111-2123

[17] S. Kant, P. Kant, H. Lips, S. Barak, "Partial substitution of $\mathrm{NO}_{3}^{-}$by $\mathrm{NH}_{4}{ }^{+}$fertilization increases ammonium assimilating enzyme activities and reduces the deleterious effects of salinity on the growth of barley". Journal of Plant Physiology, 2007, 164: 303-311

[18] B. D. Wheeler, "Water and plants in freshwater wetlands". In: Ecohydrology: Plants and Water in Terrestrial and Aquatic Environments. Routledge, London, 1999.

[19] Y. H. Xie, B. Ren, F. Li, "Increased nutrient supply facilitates acclimation to high water level in the marsh plant Deyeuxia angustifolia: the response of root morphology". Aquatic Botany, 2009, 91: 1-5

[20] J. Lissner, H. H. Schierup, F. A. Comın, V. Astorga, "Effect of climate on the salt tolerance of two Phragmites australis populations. I. Growth, inorganic solutes, nitrogen relations and osmoregulation". Aquatic Botany, 1999, 64: 317-333

[21] C. W. Yang, J. N. Chong, C. Y. Li, C. M. Kim, D. C. Shi, D. L.Wang, "Osmotic adjustment and ion balance traits of an alkali resistant halophyte Kochia sieversiana during adaptation to salt and alkali conditions". Plant and Soil, 2007, 294: 263-276

[22] M. A. Khan, I. A. Ungar, A. M. Showalter, "The effect of salinity on the growth, water status, and ion content of a leaf succulent perennial halophyte, Suaeda fruticosa (L.) Forssk". Journal of Arid Environments, 2000, 45:73-84

[23] M. Ashraf and A. Orooj. "Salt stress effects on growth, ion accumulation and seed oil concentration in an arid zone traditional medicinal plant ajwain (Trachyspermum ammi [L.] Sprague)". Journal of Arid Environments, 2006, 64: 209-220

[24] J. K .Zhu, "Regulation of ion homeostasis under salt stress". Current Opinion in Plant Biology, 2003, 6:441-445

[25] M. A. Khan, I. A. Ungar, A. M. Showalter, "Effects of salinity on growth, ion content, and osmotic relations in Halopyrum mocoronatum (L.) Stapf". Journal of Plant Nutrition, 1999, 22:191-204

[26] M. A. Khan, "Experimental assessment of salinity tolerance of Ceriops tagal seedlings and saplings from the Indus delta, Pakistan". Aquatic Botany, 2001, 70:259-268

[27] W. C. Chen, P. J. Cui, H. Y. Sun, W. Q. Guo, C. W. Yang, H. Jin, B. Fang, D. C. Shi, "Comparative effects of salt and alkali stresses on organic acid accumulation and ionic balance of seabuckthorn (Hippophae rhamnoides L.)". Industrial Crops and Products, 2009, 30: 351-358

[28] H. B. Hu, W. J. Zhang, B. L. Chen, Y. H. Wang, H. M. Shu, Z. G. Zhou, "Changes in $\mathrm{C} / \mathrm{N}$ Ratio of Subtending Leaf of Cotton Boll and Its Relationship with Cotton Boll Dry Matter Accumulation and Distribution". Acta Agronomica Sinica, 2008, 34(2): 254-260 